\title{
Analysis of the economic viability of organic production system of ornamental pineapple plants for cut stems
}

\author{
Gabriella Navarro Donato Pereira ${ }^{1}$ (1), Everton Hilo de Souza ${ }^{1}$ (), José da Silva Souza² (1), \\ Carlos Estevão Leite Cardoso ${ }^{2}\left(\mathbb{0}\right.$, Adenildo Bernardo dos $\operatorname{Santos}^{3}{ }^{(\mathbb{D} \text {, }}$ \\ Fernanda Vidigal Duarte Souza ${ }^{2 *}$ (i) \\ ${ }^{1}$ Universidade Federal do Recôncavo da Bahia (UFRB), Programa de Pós-Graduação em Recursos Genéticos Vegetais, Cruz das Almas-BA, Brazil. \\ ${ }^{2}$ Embrapa Mandioca e Fruticultura, Cruz das Almas-BA, Brazil. \\ ${ }^{3}$ Fundação José Carvalho, Escola Rural Tina Carvalho, Entre Rios-BA, Brasil.
}

\begin{abstract}
The growth of Brazilian floriculture is remarkable, both in terms of the number of producers and the cultivated area. To reduce costs and add value, the organic production of ornamental pineapple plants is an option for some consumer markets. This study was carried at the Fundação José Carvalho, municipality of Entre Rios (Bahia State), Brazil, to evaluate the economic viability of the organic production of ornamental pineapple plants, as well as to analyze the economic factors from implantation of the crop to the final production phase. Primary and secondary data collection (technical coefficients and prices) was carried out, which allowed updating the value of these coefficients. After determining the technical coefficients, input prices and product prices were surveyed and were inserted in spreadsheets of production cost and profitability. Data processing and profitability analysis were carried out under deterministic and risk conditions. The organic cultivation system for ornamental pineapples proved to be economically viable, providing greater profitability and production of stems, which is the product of interest.
\end{abstract}

Keywords: cut flowers, floriculture, ornamental pineapples, production cost.

\section{Resumo}

Análise da viabilidade econômica do sistema de produção orgânico de abacaxizeiros ornamentais voltados para corte $\mathrm{O}$ crescimento da floricultura brasileira é notável e é percebido tanto no número de produtores, quanto na área cultivada. Visando a reduzir os custos e agregar valor, a produção de abacaxizeiros ornamentais com produção orgânica pode ser uma opção direcionada a mercados consumidores. O trabalho foi conduzido na Fundação José Carvalho, Entre Rios (Bahia), Brasil, com o objetivo de avaliar a viabilidade econômica do sistema de produção orgânica de abacaxizeiros ornamentais, bem como analisar os fatores econômicos desde a implantação do cultivo à fase final de produção. Realizou-se a coleta de dados primários e secundários (matriz de coeficientes técnicos e preços), que permitiram atualizar e valorar a planilha destes coeficientes. Após os levantamentos dos coeficientes técnicos, dos preços de insumos e produtos, os mesmos foram inseridos em planilhas eletrônicas de custo de produção e rentabilidade, realizando-se os tratamentos dos dados e a análise de rentabilidade em condições determinísticas e em condições de risco. O sistema de cultivo orgânico para abacaxizeiros ornamentais se mostrou viável economicamente, proporcionando uma maior lucratividade e produção da haste, que é o produto de interesse.

Palavras-chave: flor de corte, floricultura, abacaxi ornamental, custo de produção.

\section{Introduction}

The worldwide popularity of pineapples as ornamental plants has been growing in recent years due to their beauty, originality and the postharvest durability of flowers and stems, prompting rising demand for new cultivars (Souza et al., 2012a; Costa Junior et al.,
2016; Pereira et al., 2018). Brazil is a large producer of ornamental pineapple plants, with production concentrated in the Northeast region, especially in the states of Ceará and Rio Grande do Norte. However, this commercial activity is based on only two varieties, one of them bearing large and very spiny fruits (Souza et al., 2012b; Pereira et al., 2018).

*Corresponding author: fernanda.souza@embrapa.br 
Due to the steady demand for novelty in the cut flower and ornamental plant segment, the Embrapa Cassava and Fruits research unit has been conducting research to develop new botanical materials to meet this demand (Souza et al., 2014; Pereira et al., 2018). So far this has led to the commercial launch of two ornamental pineapple cultivars, 'BRS Anauê' and 'BRS Boyrá', both in 2018 (Souza et al., 2019).

The program for genetic improvement of ornamental pineapple plants began in 2003 and aims to develop new selections and cultivars with suitable traits for landscaping, potted plants, cut flowers and ornamental mini-fruits (Souza et al., 2012a; 2012b; 2014; 2019). So far, 31 ornamental pineapple hybrids have been selected, 16 of them for cut flowers, 4 for mini-fruits, 17 for landscaping, 2 for potted plants and 1 for foliage (with some overlapping uses) (Souza et al., 2014). Furthermore, the demand for more sustainable production systems has been increasing, for which organic cultivation is an attractive alternative.

For commercial launch of a new cultivar, studies of production systems and economic feasibility are fundamental, to generate knowledge to support the development and adoption of new technologies, as well as to enable supply of a product that meets the demands of the consumer market and the needs of growers (Cavalcante et al., 2010).

The floriculture chain has been expanding in Brazil, generating employment and income throughout the country (Junqueira and Peetz, 2017; 2018; 2021). In 2019, the floriculture and ornamental plant sector generated gross retail revenue of $\mathrm{R} \$ 7,5$ billion, 4,16\% higher than in 2018 , an outstanding result considering the economic recession in the period (Junqueira and Peetz, 2021). This growing demand for ornamental fruit plants has brought a need for studies related to market parameters, both national and international, including production and distribution variables and consumer acceptance attributes. In addition, flower consumers, as with food products, have been looking for products from more sustainable systems that are less aggressive to the environment and the search for an organic approach to flowers is growing (Andrade et al., 2012; Rihn et al., 2016). More sustainable systems are in the main trends in world agriculture and, at the national level, there are practically no technical-scientific contributions to floriculture. Therefore, the development and knowledge of the costs of an organic system bring numerous advantages, not only for the producer, but also for everyone involved in this chain.

The objective of this work was to carry out an economic analysis of the organic production of ornamental pineapple plants, from planting to final distribution to the consumer market, to allow producers to evaluate the viability of the system in question based on the cost per unit produced. This information is critical for initial decisions and planning during subsequent years of cultivation.

\section{Material and Methods}

The agronomic part of the study was carried out at the Tina Carvalho Rural School of the José Carvalho Foundation (FJC), in the municipality of Entre Rios, located in the Tabuleiros Costeiros Region of the Forest Zone along the northern coast of the state of Bahia (11 $55^{\prime} \mathrm{S} 38^{\circ} 04^{\prime} \mathrm{W}$, altitude $151 \mathrm{~m})$. The Tina Carvalho Rural School is a rural alternation school dedicated to primary education that maintains experimental areas. The climate in the region is of the tropical rainforest type, with a brief dry period in the summer. The coolest month has average temperature slightly above $18^{\circ} \mathrm{C}$ and the driest month has precipitation just below $60 \mathrm{~mm}$.

The production system evaluated involved cultivation of the 'BRS Anauê' hybrid, with plant spacing of $0.90 \mathrm{x}$ $0.30 \times 0.20 \mathrm{~m}$, allowing the planting of approximately 46,000 plants in $5,500 \mathrm{~m}^{2}$. The collected data were adjusted for the cultivation system of this cultivar that holds 83,000 plants $\mathrm{ha}^{-1}$. The phytotechnical and crop treatment conditions of the organic cultivation system followed the recommendations of Matos et al. (2017). All data were collected in 2016.

The steps of the production process were monitored to collect primary data to compose a matrix of technical coefficients. The data on costs and prices were obtained in the local market, more precisely, in a florist in the cities of Salvador and Santo Antonio de Jesus, Bahia, so as to simulate real conditions. These data were used to prepare Excel $^{\circledR}$ spreadsheets, as shown in Table 1. 
Table 1. Production cost per hectare of the 'BRS Anauê' ornamental pineapple cultivar in an irrigated organic system with dual rows and spacing of $0.90 \mathrm{~m} \times 0.30 \mathrm{~m}$ x $0.20 \mathrm{~m}$ (83,333 plants). Values in reais (R\$), August 2016.

\begin{tabular}{|c|c|c|c|c|}
\hline Specification & Unit & Quant. & Price per Unit (R\$) & Value (R\$) \\
\hline \multicolumn{5}{|c|}{ Inputs } \\
\hline Plantlets & Unit & 87,500 & 0.05 & 4.375 .00 \\
\hline Dolomitic limestone & $\mathrm{T}$ & 0.5 & 60.00 & 30.00 \\
\hline Chicken manure & $\mathrm{T}$ & 30 & 150.00 & $4,500.00$ \\
\hline Biobait (ants) & $\mathrm{Kg}$ & 15 & 25.00 & 375.00 \\
\hline Floral inducer (calcium carbide) & $\mathrm{Kg}$ & 8 & 3.10 & 24.80 \\
\hline Subtotal & \multicolumn{4}{|c|}{$9,304.80$} \\
\hline Share of costs & \multicolumn{4}{|c|}{22.17} \\
\hline \multicolumn{5}{|l|}{ Soil preparation, fertilization and planting } \\
\hline Harrowing & $\mathrm{h}$ tractor $^{-1}$ & 4 & 80.00 & 320.00 \\
\hline Liming & days worker ${ }^{-1}$ & 2 & 45.00 & 90.00 \\
\hline Leveling & $\mathrm{h}$ tractor $^{-1}$ & 2 & 80.00 & 160.00 \\
\hline Distribution of various inputs & days worker-1 & 3 & 45.00 & 135.00 \\
\hline Organic fertilization (chicken manure) & days worker ${ }^{-1}$ & 45 & 45.00 & $2,025.00$ \\
\hline Plowing of the planting rows & $\mathrm{h}$ tractor $^{-1}$ or & 6 & 80.00 & 480.00 \\
\hline Transport of various inputs & $\mathrm{h}$ tractor $^{-1}$ & 1 & 80.00 & 80.00 \\
\hline Delimitation of the field (limits) & days worker ${ }^{-1}$ & 6 & 45.00 & 270.00 \\
\hline Transport of plantlets & $\mathrm{h}$ tractor $^{-1}$ & 4.5 & 80.00 & 360.00 \\
\hline Marking of plantlets spacing & days worker ${ }^{-1}$ & 15 & 45.00 & 675.00 \\
\hline Selection of plantlets & days worker ${ }^{-1}$ & 38 & 45.00 & $1,710.00$ \\
\hline Distribution of plantlets & days worker ${ }^{-1}$ & 8 & 45.00 & 360.00 \\
\hline Planting & days worker ${ }^{-1}$ & 40 & 45.00 & $1,800.00$ \\
\hline Thinning of plantlets & days worker ${ }^{-1}$ & 10 & 45.00 & 450.00 \\
\hline Subtotal & \multicolumn{4}{|c|}{$8,915.00$} \\
\hline Share of costs & \multicolumn{4}{|c|}{21.24} \\
\hline \multicolumn{5}{|c|}{ Crop and phytosanitary treatments } \\
\hline Weeding between the rows & days worker ${ }^{-1}$ & 70 & 45.00 & $3,150.00$ \\
\hline Inspection/control of ants & days worker ${ }^{-1}$ & 14 & 45.00 & 630.00 \\
\hline Floral induction & days worker ${ }^{-1}$ & 12 & 45.00 & 540.00 \\
\hline Subtotal & \multicolumn{4}{|c|}{$4,320.00$} \\
\hline Share of costs & \multicolumn{4}{|c|}{10.29} \\
\hline \multicolumn{5}{|c|}{ Irrigation } \\
\hline $\begin{array}{l}\text { Fixed costs (acquisition }+ \text { installation }+ \text { trans- } \\
\text { port)* }\end{array}$ & Cycle & 1 & $1,872.43$ & $1,872.43$ \\
\hline \multicolumn{5}{|c|}{ Variable costs (cycle) } \\
\hline Energy consumption per ha & $\mathrm{R} \$ / \mathrm{ha}$ & 1 & $1,427.43$ & $1,427.43$ \\
\hline Labor & days worker-1 & 82.5 & 45.00 & $3,712.50$ \\
\hline Irrigation water & $\mathrm{m}^{3}$ & 12,000 & 0.05 & 600.00 \\
\hline Maintenance of the irrigation system & $15 \%$ & 1 & 860.99 & 860.99 \\
\hline Subtotal & \multicolumn{4}{|c|}{$8,473,35$} \\
\hline Share of costs & \multicolumn{4}{|c|}{20.19} \\
\hline \multicolumn{5}{|c|}{ Harvest and transport } \\
\hline Harvesting of floral stems & days worker ${ }^{-1}$ & 18 & 45.00 & 810.00 \\
\hline Processing of floral stems & days worker-1 & 52 & 45.00 & $2,340.00$ \\
\hline Processing water & $\mathrm{m}^{3}$ & 120 & 3.50 & 420.00 \\
\hline Electricity & Kwh & 1 & 495.00 & 495.00 \\
\hline
\end{tabular}


Table 1. cont.

\begin{tabular}{|c|c|c|c|c|}
\hline Subtotal & \multicolumn{4}{|c|}{$4,065.00$} \\
\hline Share of costs & \multicolumn{4}{|c|}{9.69} \\
\hline \multicolumn{5}{|c|}{ Other costs } \\
\hline Transport of plantlets & Unit & 1 & 700.00 & 700.00 \\
\hline Transport of soil corrective & Unit & 1 & 600.00 & 600.00 \\
\hline Transport of organic fertilizer (chicken manure) & Unit & 2 & 145.00 & 290.00 \\
\hline Additional $5 \%$ for design (of the previous costs) & Unit & 1 & $1,833.41$ & $1,833.41$ \\
\hline Subtotal & \multicolumn{4}{|c|}{$3,423,41$} \\
\hline Share of costs & \multicolumn{4}{|c|}{8.16} \\
\hline \multicolumn{5}{|c|}{ Financial charges } \\
\hline Financial charges ( $6 \%$ p.a. for 18 months) & $\%$ & 9 & $38,501.56$ & $3,465.14$ \\
\hline Subtotal & \multicolumn{4}{|c|}{$3,465.14$} \\
\hline Share of costs & \multicolumn{4}{|c|}{8.26} \\
\hline Effective operating cost & \multicolumn{4}{|c|}{$41,966.70$} \\
\hline Total & \multicolumn{4}{|c|}{100.00} \\
\hline \multicolumn{5}{|c|}{ Land cost } \\
\hline Lease/equivalent cost & $\mathrm{R} \$ /$ year & 2 & 500.00 & $1,000.00$ \\
\hline Total operating cost & \multicolumn{4}{|c|}{$42,966.70$} \\
\hline
\end{tabular}

* The useful life of equipment was considered to be 10 years.

IGP-DI (August 1994=100 and August 2016 = 647.153. Exchange rate (August 2016, R $\$ /$ US $\$=3.2091$ ).

After elaboration of the spreadsheets, two analyses were carried out: on in deterministic conditions and the other considering the risks associated with the production process.

To update the values in Table 1 for inflation, we used the General Market Price Index (IGP-DI) computed by Getúlio Vargas Foundation (FGV), where August $1994=100$ and August $2016=647.153$ or the exchange rate with the US dollar $(\mathrm{R} \$ / \mathrm{US} \$)=3.2091$. However, to make decisions in specific cases, we recommend using a vector of production factor prices and the price of the final product updated for inflation to the desired moment.

A benefit/cost ratio equal to 2.00 means that for each R $\$$ 1.00 invested, the gross return is $\mathrm{R} \$ 2.00$ and the net return is $\mathrm{R} \$ 1.00$ during the cultivation period (approximately 18 months).

\section{Deterministic analysis}

The deterministic analysis involved calculating the following profitability indicators: gross margin, benefit/ cost ratio, break-even point, safety margin and unit cost. The gross margin corresponds to the difference between the inputs (revenues $=\mathrm{B}$ ) and outputs (expenses $=\mathrm{C}$ ), giving an indicator of the amount of gross profit from each production cycle. The benefit/cost ratio $(\mathrm{B} / \mathrm{C})$ is the ratio between revenues and expenses, indicating the return on each monetary unit invested, here calculated in Brazilian currency, the real (plural reais, R\$).

The break-even point indicates the number of pineapples stems necessary to generate sufficient net revenue to pay the total costs, i.e., the number of stems that need to be produced to avoid a loss from the undertaking. The safety margin, in turn, indicates the maximum reduction percentage that could be applied, individually, to the variables that compose the total revenue (yield and product price) so that the production costs would still be covered.

We also calculated the unit cost, denoting the cost of each stem, obtained by the ratio between the total cost and total production in stems/hectare/cycle.

\section{Risk-related analysis}

The risk-related analysis allowed identifying the most important variables affecting the production costs of ornamental pineapple plants and the profitability of the activity. We considered the following cost variables: average irrigation cost; cost and number of machines used (hours/tractor); labor cost (cost of men/day and number of men/day); cost and amount of chicken manure applied (metric tons), and number of plantlets. On the revenue side, we considered the average wholesale price of an ornamental pineapple stem.

\section{Monte Carlo simulation method}

The variables of greatest importance in the composition of the profitability/sensitivity indicators identified above were used in Monte Carlo simulation, which is widely used in risk analysis (Martins et al., 2016). According to Noronha (1987), Monte Carlo simulation consists of four steps:

$1^{\text {st }}$ step: Choice of the most relevant variables.

We chose the technical coefficients with greatest relevance for the cost of growing ornamental pineapple plants (organic cultivation). Then we identified the 
probability distribution of each of the relevant variables. We used a triangular distribution for the following variables: average irrigation cost; cost and number of hours/tractor; labor cost (cost of men day ${ }^{-1}$ and number of men day $^{-1}$ ); cost and amount of chicken manure; productivity (number of stems/ha/cycle); and number of plantlets.

In the case of triangular distributions, it is necessary to know the minimum value, the most likely value and the maximum value to determine the distribution of values to be used.

To ascertain the stem price variable, we used the tools of the Crystal Ball ${ }^{\circledR}$ software, to identify the best probability distribution by analysis of the historic series of prices (Crystal, 2005).

$2^{\text {nd }}$ step: Definition of the value of each variable, based on its probability distribution.

This step was also carried out with the support of the Crystal Ball ${ }^{\circledR}$ software, to obtain at random the values for the chosen variable based on the probability distributions identified in the previous step.

$3^{\text {rd }}$ step: Calculation of profitability indicators.

The profitability indicators calculated were: benefit/ cost ratio $(\mathrm{B} / \mathrm{C})$; break-even point; gross margin; and unit cost. The simulated values were used to replace the original values in the cost spreadsheet, obtaining new values of these indicators of profitability/sensitivity.

4th step: Repetition of the process.

The process was repeated (10,000 simulations) until obtaining a suitable frequency distribution for the chosen indicators. This distribution served to support making decisions.

\section{Sensitivity analysis}

The sensitivity analysis consisted of determining the effect caused by the variation of the costs of inputs, labor cost, irrigation system cost, cost/hour/tractor and yield of ornamental pineapple stems on the chosen profitability indicators: benefit/cost ratio $(\mathrm{B} / \mathrm{C})$, break-even point, gross margin and unit cost. This process allowed estimating to what extent changes in the variables of the production system can affect the expected profitability results (Buarque, 1991). This analysis was also conducted with the Crystal Ball ${ }^{\circledR}$ program, to calculate the pairwise correlation coefficients between all the simulated variables and indicators of profitability considered in the study (Crystal, 2005).

\section{Results and Discussion}

\section{Deterministic analyses}

Table 1 presents the production costs per hectare of the 'BRS Anauê' ornamental pineapple cultivar in an irrigated organic production system. Like any other agricultural activity, planning is an important step and should consider the following aspects: the cultivar selected; the local climate; soil parameters; plant spacing; crop treatments; incidence of pests and diseases; costs of inputs; and market value of the product, among others. The planning phase is followed by planting, monitoring and harvesting, which should be carried out according to the planning to obtain the estimated economic return.

In a typical system for irrigated organic production of ornamental pineapple, approximately 83,000 plants ha $^{-1}$ are planted and about 75,000 stems are harvested. This is based on harvesting one stem per plant, with the difference of $10 \%$ due to the occurrence of several factors, the most important of which are early natural flowering, attacks by pests and diseases and failure of floral induction.

The costs of inputs, soil preparation and fertilization, and sowing and irrigation are the most important, with percentages of $22.17 \%, 21.24 \%$ and $20.19 \%$, respectively. These are followed by crop and phytosanitary treatments, with $10.29 \%$, and costs of harvesting and transport, with $9.69 \%$. We also considered the following costs: other costs (miscellaneous transport and design costs), financial charges and land cost. The total cost of this system was $\mathrm{R} \$ 42,966.70$ per hectare (considering values of August 2016), indicating the need for a considerable investment, and hence the need to pay attention to the appropriate technical recommendations. The unit cost, based on the total costs and the quantity of marketable stems, was $\mathrm{R} \$$ $0.57 /$ stem.

Complex horticultural production systems often lack formal support for strategic and important decisions. This deterministic analysis translates the available information on costs, benefits and risks that should be involved in production management decisions and recommendations, as well as decisions about phytotechnical and disease management strategies in the production of ornamental plants (Ruett et al., 2020). This work is the first report with this approach to the production of ornamental pineapple stems in an organic system, which has been adopted by small producer cooperatives linked to the José Carvalho Foundation in the State of Bahia, which has been carrying out an important social work with small farmers.

\section{Profitability analysis}

In the profitability analysis (Table 2), we used an average wholesale price of $\mathrm{R} \$ 1.14 \mathrm{stem}^{-1}$ considering production of $75,000 \mathrm{stems} \mathrm{ha}^{-1}(90 \%$ of the total number of plants, assuming a loss factor of $10 \%$ ). This means gross revenue of $\mathrm{R} \$ 85,500.00$ per hectare, and gross margin of $\mathrm{R} \$ 42,533.30$ after deducting the production cost $(\mathrm{R} \$$ $42,966.70$ ), leading to an excellent benefit/cost ratio of 1.99 , yielding a gross return of $\mathrm{R} \$ 1.99$ for every $\mathrm{R} \$ 1.00$ invested, or a net profit of R\$ 0.99 . 
Table 2. Observed values per hectare of the 'BRS Anauê' ornamental pineapple cultivar grown in an irrigated organic system in double rows. Values in reais (R\$), August 2016.

\begin{tabular}{|c|c|}
\hline Unit & Observed Values \\
\hline Productivity (stems) & 75,000 \\
\hline Average wholesale stem price (R\$) & 1.14 \\
\hline Value of production (B) (R\$) & $85,500.00$ \\
\hline Total operating cost (R\$) (C) & $42,966.70$ \\
\hline Gross margin (R\$) (B-C) & $42,533.30$ \\
\hline Benefit/cost ratio (B/C) & 1.99 \\
\hline Cost per stem (R\$) & 0.57 \\
\hline Break-even point (stems) & 37,690 \\
\hline Safety margin (\%) & -49.75 \\
\hline
\end{tabular}

Source: Basic research data.

IGP-DI (August 1994=100 and August 2016 = 647.153). Exchange rate (August 2016, R\$/ US\$=3.2091).

Additional information on the profitability of this system was obtained by the sensitivity analysis, by applying two indicators: a) break-even point - indicating that 37,690 stems are needed to cover the production costs; and b) safety margin - indicating the maximum reduction $(-49.75 \%)$ that can be applied, individually, to the variables that compose the total revenue (productivity and average sale price per stem) while still covering the production costs.

Therefore, for a given stem yield and applying a reduction factor of $49.75 \%$ to the variable $(75,000$ stems $)$, it was possible to obtain the number of stems necessary to cover the total production cost. In turn, applying a reduction factor of $49.75 \%$ to the average stem production cost (R\$ 1.14 stem $^{-1}$ ) gave the average minimum price necessary to pay the total cost of production. This is a fundamental analysis, not only to measure the profits, but it allows the production planning when associated with the technical information pertinent to this cultivation, as well as it allows to establish which would be the most limiting aspects for this type of cultivation. In the present work, the most significative costs are concentrated in soil preparation, fertilization, sowing and irrigation. Among these activities, the availability of water can be one of the limiting factors for cultivation. In previous works with ornamental pineapple stems, Costa Junior et al. (2016) determined all stages of production, in days, from the beginning of flowering to the final cut of the stems, as well as, technical information for the cultivation of ornamental pineapples for stems are available (Carvalho et al., 2014), but none economic study was carried out.

In a study to analyze the production cost and profitability of growing cut roses in a greenhouse in the municipality of Atibaia, São Paulo. Matsunaga et al. (1995) provided an initial parameter to growers in a floriculture market lacking information. The results of this study showed that the increase in productivity was the aim that should be pursued by growers, mainly at that time of market opening in the country. The profitability of growers according to the prices observed in that year, satisfied their expectations.

Arieira et al. (2008) conducted a study in March to October 2006 at a flower farm in the municipality of Unituarama in northwestern Paraná. The authors evaluated the economic feasibility of producing chrysanthemums and roses, finding this combination was a workable alternative for growers with small and midsize operations, and that the market for cut flowers was expanding in Brazil. The authors concluded that growing roses and chrysanthemums could be lucrative, because all the profitability indices (net and gross) were positive. Both works highlight the importance of economic studies to help producers understand what needs to be invested and the results that can be obtained in terms of profitability. More importantly, they showed the viability of the organic system of ornamental pineapple stems.

In general, the cultivation of any type of flower must be done appropriately, to reduce losses due to spoilage, since flowers are highly perishable. Thus, it is important to maintain a structure in good condition staffed by employees who are trained to handle flowers.

\section{Risk analysis}

The values considered for the variables relevant to determine the profitability of growing ornamental pineapple are presented in Table 3. Based on these values (obtained in the deterministic analysis), we defined the minimum, mean and maximum values of average irrigation cost, cost per hour/tractor, labor cost (wages and number of men/day), cost and amount of chicken manure, productivity (number of stems), number of hours/tractor, and number of plantlets, and assigned a variation range of $+/-10 \%$ in relation to the mean value. 
Table 3. Values attributed to the variables considered in the simulation (triangular distribution). Values in reais (R\$), August 2016.

\begin{tabular}{|c|c|c|c|}
\hline Variables & Minimum value & Probable value & Maximum value \\
\hline Irrigation cost (R\$) & $4,284.76$ & $4,760.85$ & $5,236.93$ \\
\hline Cost/hour/tractor (R\$) & 72.00 & 80.00 & 88.00 \\
\hline Cost of chicken manure (R\$) & 135.00 & 150.00 & 165.00 \\
\hline Productivity (number of stems) & 67,500 & 75,000 & 82.500 \\
\hline Quantity of chicken manure (t) & 27 & 30 & 33 \\
\hline Number of hours/tractor (h tr-1) & 15.75 & 17.50 & 19.25 \\
\hline Number of stems (units) & 78,750 & 87,500 & 96,250 \\
\hline Number of workers (days worker ${ }^{-1}$ ) & 373.95 & 415.50 & 457.05 \\
\hline Labor price (R\$/day/worker) & 40,50 & 45,00 & 49,50 \\
\hline
\end{tabular}

Source: Basic research data. Crystal Ball ${ }^{\circledR}$ software.

IGP-DI (August 1994=100 and August 2016 = 647.153). Exchange rate (August 2016, R\$/US\$=3.2091).

Therefore, the average irrigation cost corresponded to $\mathrm{R} \$ 4,760.85$, ranging from $\mathrm{R} \$ 4,284.76$ (minimum) to $\mathrm{R} \$ 5,236.93$ (maximum). The irrigation cost value is for 1 hectare. Considering that the costs are for a crop's production cycle, the fixed costs were calculated based on: the total fixed cost of irrigation equipment, an interest rate, redemption value (scrap), useful life of the equipment and in the capital recovery factor. Therefore, the fixed cost was adjusted for the period of the crop cycle. In turn, the average hourly cost per tractor was R $\$ 80.00$, with maximum and minimum values of $\mathrm{R} \$ 72.00$ and $\mathrm{R} \$$ 88.00 respectively. Finally, the price of chicken manure had an average of $\mathrm{R} \$ 150.00 \mathrm{t}^{-1}$, ranging from $135.00 \mathrm{t}^{-1}$ to $\mathrm{R} \$ 165.00 \mathrm{t}^{-1}$. With respect to labor, the most probable number (average) was 415.50 daysworker $^{-1}$, according to the data available for the production system in the municipality of Entre Rios, Bahia. The corresponding minimum and maximum values were 373.95 days worker $^{-1}$ and 457.05 daysworker ${ }^{-1}$ respectively, at a daily cost of R\$ 45.00 .
For productivity we also considered a variation of $10 \%$, with an average yield of 75,000 plants $\mathrm{ha}^{-1}$, ranging from 67,500 plants $^{-1} \mathrm{a}^{-1}$ to 82,500 plants $\mathrm{ha}^{-1}$. In this analysis, we considered the harvest of one stem per plantlets per cycle.

With respect to the use of chicken manure, the most likely quantity was 30 tons, with minimum of $27 \mathrm{t}$ and maximum of $33 \mathrm{t}$ and cost of $\mathrm{R} \$ 150.00$ per ton, corresponding to the most probable final cost of $\mathrm{R} \$ 4,500.00$. Regarding the number of hours tractor ${ }^{-1}$, we obtained a most likely value of $17.50 \mathrm{~h}$ tractor $^{-1}$, varying from $15.75 \mathrm{~h}_{\text {tractor }}{ }^{-1}$ to $19.75 \mathrm{~h}$ tractor $^{-1}$. The hourly cost/tractor considered was R $\$ 80.00$.

In the case of the number of plants, we found a most probable value of 87,500 plants per hectare, with respective minimum and maximum values 78,750 and 96,250.

Based on the values obtained in the deterministic analysis and the probability distributions of the variables, we obtained new values of the profitability indicators: benefit/cost ratio $(\mathrm{B} / \mathrm{C})$; break-even point; unit cost; and gross margin, after 10,000 Monte Carlo simulations (Table 4, Figure 1). 

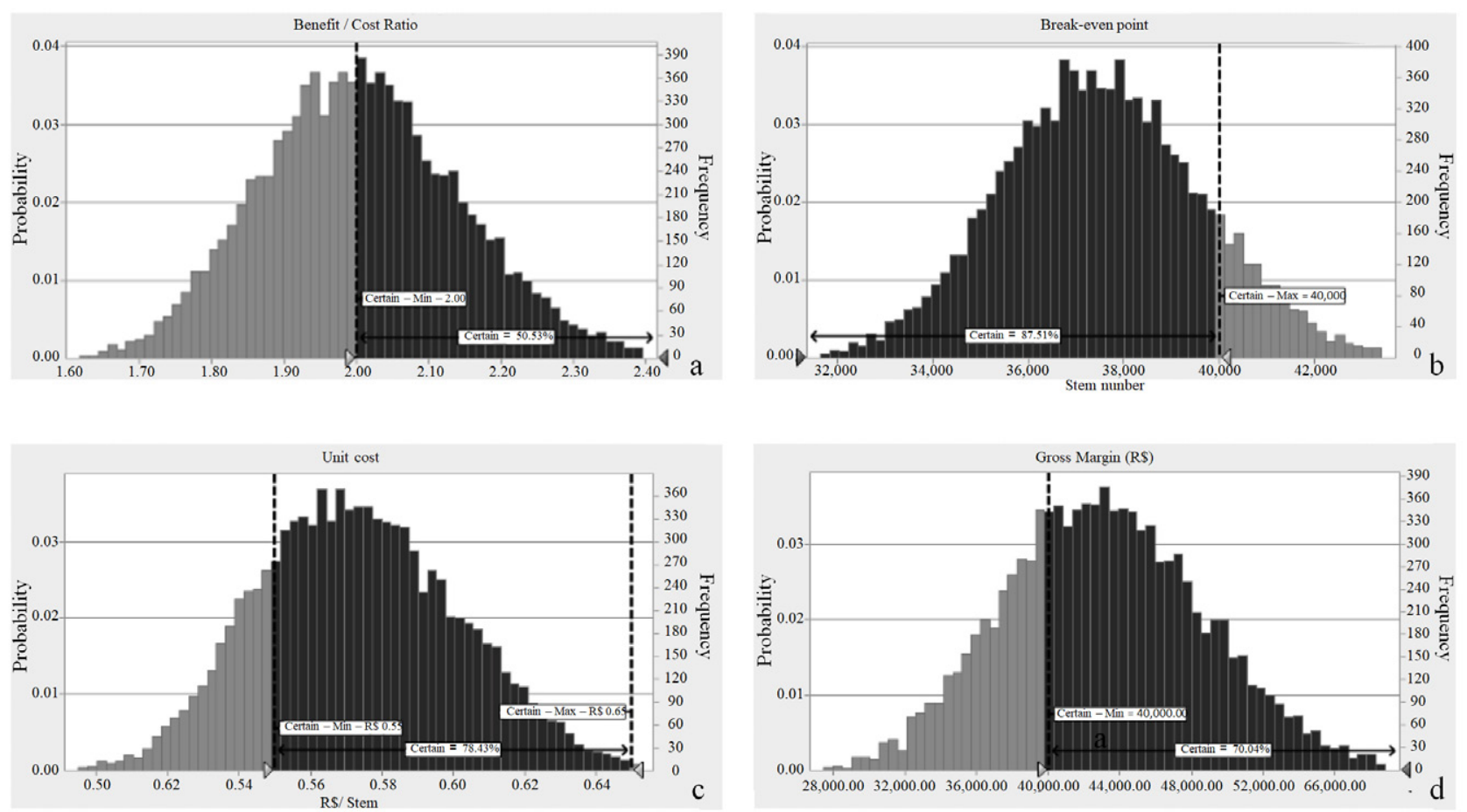

Figure 1. Probability distribution and associated frequency: benefit/cost ratio (a); break-even point (number of stems) (b); unit cost (R\$/stem) (c); and gross margin (R\$) (d). Source: Basic research data. Crystal Ball software.

Table 4. Values of the profitability/sensitivity indicators analyzed. Values in reais (R\$), August 2016.

\begin{tabular}{|c|c|c|c|}
\hline $\begin{array}{c}\text { Profitability/sensitivity } \\
\text { indicators }\end{array}$ & $\begin{array}{c}\text { Interval of variation } \\
\text { (minimum and maximum values) }\end{array}$ & Base value & Level of probability (\%) \\
\hline Benefit/cost ratio (B/C) & $1.61-2.57$ & 1.99 & $50.53 \%$ \\
\hline Break-even point (stems) & $31,043-44,691$ & 37,690 & $87.51 \%$ \\
\hline Unit cost (R\$stem) & $0.49-0.67$ & 0.57 & $78.43 \%$ \\
\hline Gross margin (B-C) $(\mathrm{R} \$)$ & $26,890.82-64,206.78$ & $42,533.30$ & $70.04 \%$ \\
\hline
\end{tabular}

Source: Basic research data.

IGP-DI (August 1994=100 and August 2016=647.153). Exchange rate (August 2016, R\$/ US\$=3.2091).

The benefit/cost ratio varied from 1.61 to 2.57 , with a probability of $50.53 \%$ of being greater than 2.00 . In other words, the activity in question has low risk when considering all the technical coefficients, costs/prices and products used in the simulation (Figure 1A).

In the simulation of the break-even point, the number of stems necessary to cover the production costs varied from 31,043 to 44,691 stems with an $87.51 \%$ probability of being lower than 40,000 stems harvested during the cycle (Figure 1B). Therefore, comparison with the expected average productivity (stems/ha) of 75,000 indicated low risk of the activity.

For the unit cost, we considered the initial value of R\$ $0.57 \mathrm{stem}^{-1}$, while the simulations led to a range of R $\$ 0.49$ to $\mathrm{R} \$ 0.67$, with a probability of $78.43 \%$ when the unit cost was between $\mathrm{R} \$ 0.55$ and $\mathrm{R} \$ 0.65$ (Figure 1C).

In relation to the gross margin indicator, the simulations produced variation from $\mathrm{R} \$ 26,890.82$ to $\mathrm{R} \$ 64,206.78$ per hectare, and $70.04 \%$ probability of being higher than $\mathrm{R} \$$ 40,000.00 (Figure 1D).

The analyses of the impacts of the simulated variables on the indicators considered (benefit/cost ratio, breakeven point, gross margin and unit cost) indicated that in determining the variables that caused stability/instability in the benefit/cost ratio, those that stood out were sale price of stems (50.1\%) and stem yield (35.1\%) (Figure 2A), with a high correlation between the two in forming the value of the benefit/cost ratio. The variables with the strongest negative influence were daily cost of workers $(-7.2 \%)$ and number of workers per day (-6.1\%). 

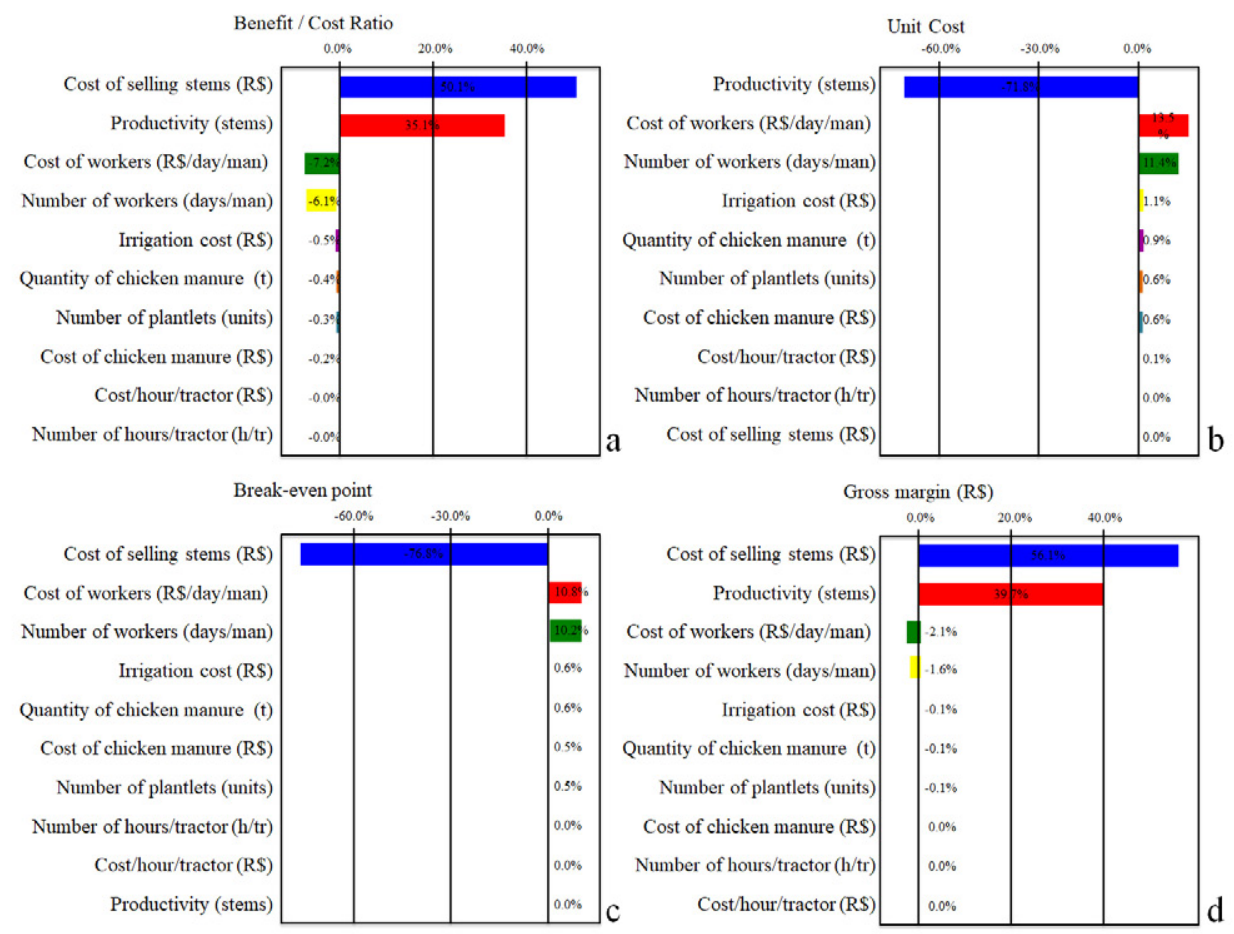

Figure 2. Sensitivity analysis of the benefit/cost ratio (a), unit cost (b), break-even point (c) and gross margin (d). Source: Basic research data. Crystal Ball software.

For the unit cost (total cost divided by the total production of stems), the cost of workers/day (13.5\%) and the number of workers/day $(11.4 \%)$ had the greatest positive effect. Therefore, the increase of these coefficients would directly affect the unit cost of growing ornamental pineapples, raising it. On the other hand, the yield (number of stems), with value of $-71.8 \%$, was the variable with the most significant effect on the unit cost, reducing it (Figure 2B).

With respect to the break-even point, among the variables that influenced this variable the most important was the sale price of the stems, with an influence of $-76.8 \%$ (Figure 2C).

For gross margin, the variations of the sale price of stems (56.1\%) and yield (number of stems/ha/cycle) (39.7\%) had the greatest effects, with high positive correlations in determining the value of the gross margin (Figure 2D).

The results obtained in this work show a promising scenario for the organic cultivation of ornamental stems of 'BRS Anauê', despite the initial investment being considered relatively high. The unit cost found, of $\mathrm{R} \$ 0.57 \mathrm{stem}^{-1}$, was more than offset when considering the average wholesale price of $\mathrm{R} \$ 1.14 \mathrm{stem}^{-1}$ and production of 75,000 stems per hectare. Therefore, we obtained gross revenue of R\$ 85,500.00, which after deducting the production cost worked out to a gross margin of $\mathrm{R} \$ 42,533.30$ and an excellent benefit/cost ratio of 1.99. Furthermore, the profitability indicators of the deterministic analysis (safety margin and break-even point) were also excellent. The safety margin of $-49.75 \%$ implied sufficient capacity and flexibility to the activity to face the risks associated with both productivity and average price per stem and still cover the production costs. The break-even point of 37,690 stems ha ${ }^{-1}$ also indicated good profitability.
The indicators of profitability (benefit/cost ratio, breakeven point, unit cost and gross margin) obtained from the analysis of the irrigated organic production system of ornamental pineapple plants considering risks revealed the activity has low risk besides good profitability.

The sale price of stems ( $\mathrm{R} \$ /$ stem) and productivity (number of stems $\mathrm{ha}^{-1}$ ) were the variables with the strongest impact on the profitability indicators. Thus, the high sensitivity of the profitability indicators to these two variables indicates the need for special attention, particularly to the sale price, which is an exogenous variable, outside the control of the producers. Notwithstanding the good safety margin of the production system revealed in the risk analysis, attention to productivity should not be overlooked due to the impacts on the composition of the unit cost and safety margin.

A system of organic production of ornamental pineapples is undoubtedly a valuable technology to be made available to farmers. Thus, it is important to know the degree of risk that exists in the implementation of the technology, since economic viability is a fundamental factor for the adoption of new technologies among farmers (Feitosa et al., 2018).

It is important to highlight that the cultivation of 1 ha of ornamental pineapple yields a large number of stems, as already mentioned, which makes evident the need for production planning. Floral induction allows this production to be scaled according to market demand. In Brazil, the company ABX Tropical Flowers, in Rio Grande do Norte state, has its entire production system adjusted to meet export demands, including the peaks of commemorative dates (personal communication), including 'BRS Anauê' and 'BRS Boyrá' in its products. 
In the case of ornamental pineapple, which has been grown for export (Oliveira et al., 2010), the adoption of this production system, with the low risk observed in production and the unit price of the stem, can be a differential. Another factor to be considered is the increased demand from European consumers for products from more sustainable systems.

\section{Conclusions}

In the deterministic analysis of the irrigated organic system for production of the 'BRS Anauê' ornamental pineapple cultivar, the results were very promising;

The economic analysis of the organic cultivation system for ornamental pineapple showed the profitability of the enterprise, as well as the possibility of planning for production scaling.

\section{Author Contribution}

GNDP, ABS: conceptualization, methodology, investigation, data curation and writing-original draft. EHS, JSS, CELC: conceptualization, visualization, methodology, formal analysis, writing - review \& editing and supervision. FVDS: conceptualization, resources, visualization, formal analysis, writing-review \& editing, supervision and financing.

\section{Acknowledgments}

This paper is part of GSN MSc dissertation and this study was financed in part by the Coordenação de Aperfeiçoamento de Pessoal de Nível Superior - Brasil (CAPES) - Finance Code 001. The authors would like to thank the support from the Fundação José Carvalho, Escola Rural Tina de Carvalho. EHS acknowledges the support of CAPES/PNPD/UFRB (88882.315208/2019-01) and FVDS currently holds a productivity grant from the Conselho Nacional de Desenvolvimento Científico e Tecnológico (CNPq 304269/2018-2).

\section{References}

ANDRADE, L.O; GHEYI, H.R.; NOBRE, R.G.; DIAS, N.S.; NASCIMENTO, E.C.S. Crescimento de girassóis ornamental em sistema de produção orgânica e irrigada com água residuária tratada. Irriga, v.1, n.1, p.69-82, 2012. https://doi.org/10.15809/irriga.2012v1n01p69

ARIEIRA, C.R.D.; MORITA, D.A.S.; ARIEIRA, J.O.; CODATO, J.M. Análise da viabilidade econômica para produção de flores em Umuarama, noroeste do Paraná. Revista Agroambiente, v.2, n.2, p.33-41, 2008. http:// dx.doi.org/10.18227/1982-8470ragro.v2i2.237

BUARQUE, C. Avaliação econômica de projetos. Rio de Janeiro: Campus, 1991. 266p.

CARVALHO, A.C.P.P.; SOUZA, F.V.D.; SOUZA, E.H. Produção de abacaxizeiro ornamental para flor de corte. Fortaleza: Embrapa Agroindústria Tropical, 2014. 44p.
CAVALCANTE, R.A.; MOSCA, J.L.; SOUSA, A.B.O.; FEITOSA, D.R.C.; PAIVA, W.O. Desenvolvimento e pós-colheita de abacaxi ornamental. Revista Brasileira de Horticultura Ornamental, v.16, n.1, p.101-105, 2010. https://doi.org/10.14295/rbho.v16i1.517

COSTA JUNIOR, D.S.; SOUZA, E.H.; COSTA, M.A.P.C.; PEREIRA, M.E.C.; SOUZA, F.V.D. Clonal evaluation of new ornamental pineapple hybrids to use as cut flowers. Acta Scientiarum. Agronomy, v.38, n.4, p.1-12, 2016. https://doi.org/10.4025/actasciagron.v38i4.26495

CRYSTAL BALL PROFESSIONAL 7. Guia prático. Denver: Decisioneering, Inc., 2005. 100p.

FEITOSA, E.O.; ARAÚJO, A.F.B.; LOPES, F.B.; ANDRADE, E.M.; BEZERRA, F.M.L. Análise de custo e rentabilidade na produção de mamão irrigado no semiárido. Revista Brasileira de Agricultura Irrigada, v.12, n.1, p.2293-2304, 2018.

JUNQUEIRA, A.H.; PEETZ, M. Intellectual property rights in Brazilian floriculture: innovations for the growth and development of the market. Ornamental Horticulture, v.23, n.3, p.296, 2017. https://doi.org/10.14295/ oh.v23i3.1071

JUNQUEIRA, A.H.; PEETZ, M. Sustainability in Brazilian floriculture: introductory notes to a systemic approach. Ornamental Horticulture, v.24, n.2, p.155-162, 2018. https://doi.org/10.14295/oh.v24i2.1253

JUNQUEIRA, A.H.; PEETZ, M.S. Plantas ornamentais para ambientes interiores sustentam o desempenho da floricultura na pandemia. Agrianual: Anuário da Agricultura Brasileira. p. 286-289. São Paulo: IHS Markit, 2021.

MARTINS, E.A.; CAMPOS, T.C.; CAMPOS, K.C.; ALMEIDA, C.S. Rentabilidade da produção de acerola orgânica sob condição determinística e de risco: estudo do distrito de irrigação Tabuleiro Litorâneo do Piauí. Revista de Economia e Sociologia Rural, v.54, n.1, p.9-28, 2016. https://doi.org/10.1590/1234-56781806-9479005401001

MATOS, A.P.; PADUA, R.R.P.; CORDEIRO, Z.J.M. Sistema orgânico para produção de abacaxi para Lençóis, Chapada Diamantina - BA. Sistema de Produção da Embrapa Mandioca e Fruticultura, v.45, online, 2017.

MATSUNAGA, M.; OKUYAMA, M.H.; BESSA JUNIOR, A.A. Cultivo em estufa de rosa cortada: custos e rentabilidade. Informações Econômicas, v.25, n.8, p.4958, 1995.

NORONHA, J.F. Projetos agropecuários: administração financeira, orçamento e viabilidade econômica. São Paulo: Editora Atlas S/A, 1987. 269p. 
OLIVEIRA, Y.; ANSELMINI, J.I.; CUQUEL, F.L.; PINTO, F.; QUOIRIN, M. Pré-aclimatização in vitro de abacaxi-ornamental. Ciência e Agrotecnologia, v.34, n.1, p.1647-1653, 2010. https://doi.org/10.1590/S141370542010000700010

PEREIRA, G.N.D.; SOUZA, E.H.; SOUZA, J.S.; SOUZA, F.V.D. Public perception and acceptance of ornamental pineapple hybrids. Ornamental Horticulture, v.24, n.2, p.116-124, 2018. https://doi.org/10.14295/oh.v24i2.1154

RIHN, A.; KHACHATRYAN, H.; CAMPBELL, B.; HALL, C.; BEHE, B. Consumer preferences for organic production methods and origin promotions on ornamental plants: evidence from eye-tracking experiments. Agricultural Economics, v.47, n.6, p.599-608, 2016. https://doi.org/10.1111/agec.12258

RUETT, M.; WHITNEY, C.; LUEDELING, E. Modelbased evaluation of management options in ornamental plant nurseries. Journal of Cleaner Production, v. 271, e-122653, 2020. https://doi.org/10.1016/j. jclepro.2020.122653
SOUZA, E.H.; COSTA, M.A.P.C.; SANTOS-SEREJO, J.A.; SOUZA, F.V.D. Selection and use recommendation in hybrids of ornamental pineapple. Revista Ciência Agronômica, v.45, n.2, p.409-416, 2014. https://doi. org/10.1590/S1806-66902014000200024

SOUZA, E.H.; SOUZA, F.V.D.; COSTA, M.A.P.C.; COSTA JÚNIOR, D.S.; SANTOS-SEREJO, J.A.; AMORIM, E.P.; LEDO, C.A.S. Genetic variation of the Ananas genus with ornamental potential. Genetic Resources and Crop Evolution, v. 59, p. p. 1357-1376, 2012a. https://doi. org/10.1007/s10722-011-9763-9

SOUZA, F.V.D.; CARVALHO, A.C.P.P.; SOUZA, E.H. Abacaxi Ornamental. In: PAIVA, P.D.O.; ALMEIDA, E.F.A. Produção de Flores de Corte. Lavras: Editora Universitária - UFLA, 2012b. p.19-39.

SOUZA, F.V.D.; SOUZA, E.H.; SANTOS-SEREJO, J.A.; CABRAL, J.R.S. BRS Anauê and BRS Boyrá: the first cultivars of ornamental pineapple developed in Brazil. Crop Breeding and Applied Biotechnology, v.19, n.3, p.382-386, 2019. http://dx.doi.org/10.1590/198470332019 v19n3c54 